International Journal of Social Science (IJSS)

Vol.1 Issue.5 February 2022, pp: 637-642

ISSN: 2798-3463 (Printed) | 2798-4079 (Online)

\title{
THE EFFECT OF THE COVID-19 PANDEMIC ON PIETY AND SOCIAL SOLIDARITY OF CATHOLIC PEOPLE IN PONTIANAK ARCHDIOCESE
}

\author{
By \\ Kristianus ${ }^{1}$, Laurentius Prasetyo ${ }^{2}$, Mikael Dou Lodo ${ }^{3}$ \\ ${ }_{1,2,3}$ Pontianak State Catholic College \\ Email: ${ }^{1}$ kristianusatok@gmail.com, ${ }^{2}$ Laurentius.prasetyo70@gmail.com, ${ }^{3}$ Mikaeldou686@gmail.com
}

\begin{tabular}{l}
\hline Article Info \\
\hline Articlehistory: \\
Received Nov 13, 2021 \\
Revised Dec 22, 2021 \\
Accepted Jan 24, 2022
\end{tabular}

Keywords:

Covid-19 Pandemic, Catholic, Social Generosity, Believers.

\begin{abstract}
This research was motivated by the Covid-19 pandemic that struck the world from March 2020 until today. This pandemic has changed the religious ritual of the Catholic religion around the world from the model of Mass congregation at church to online mass congregation at their homes. This mass congregation service at home indeed changed social interaction patterns. This research aims to investigate whether people's piety and social solidarity also changed with the mass service at home. By combining qualitative and quantitative methods during the last five months, this research finally found that, on the contrary, people's piety and social solidarity improved. It turns out that they are far more religious in their lives and very care about the catholic follower's life and other religious believers. This research has also made the church conduct paradigm reform in serving the people. The church has conducted a new kind of service in this New Normal era, i.e., Profilingcustomers. The church has studied their served people thoroughly. How is their profile, what do they need, and their expectation? The church has set customer focus, friendly, consistent, and continuous improvement. It is an effort to establish the people to the new performance style. The church is expected to keep on formulating new ways to overcome the shock of appreciation of faith due to this pandemic. In life, faith always has ups and downs; that is a portrait of human nature. This era is uncertain, but people will survive and live on. We are looking at the new face of the church, especially regarding piety and social solidarity of the people.
\end{abstract}

Thisisan open accessarticleunderthe CC BY-SAlicense.

\author{
CorrespondingAuthor: \\ Kristianus \\ Pontianak State Catholic College \\ Email: kristianusatok@gmail.com
}

\section{INTRODUCTION}

The Indonesian Catholic church fully supports the government's effort in containing the new variant of coronavirus or Covid-19. The catholic church has not held the daily and weekly mass congregation and all religious rituals that involve and invites many people to gather,both at the parish, neighborhood, regional and so on; starting from March 2021 until the end of 2021, the service has to be done only at home(Magdalena et al., 2021).

This decision was ordered from the center of the catholic church in Vatikan, and the Indonesian catholic church obeyed and followed up this decision accordingly (Karnawati \& Mardiharto, 2020). Since Sunday 22 March 2020, nearly all catholic churches have abolished the church's Mass service, including in Pontianak Archdiocese, which oversees several districts in West Kalimantan.

Even though Sunday worship at the church is abolished, people can still attend Mass online (live streaming) because all churches in Pontianak Archdiocese simultaneously hold the live streaming Mass simultaneously with different times and durations. This Mass service makes the believers or participants interact less with the other people. Their interaction among the followers is only through online. Moreover, social deeds also have shifted their forms. 
The online mass, held for the first time in history at the Pontianak Archdiocese, was enthusiastically followed by Catholic believers in their respective homes.Although the atmosphere is slightly different from the mass at church, the Catholics follow the online mass solemnly and peacefully. The thing is, there has never been a study on the impact of this pandemic on the piety and social solidarity of Catholic believers.

Generally, the formulation of problems in this research is how does the COVID-19 pandemic affect Catholics' piety and social actions in the Pontianak Archdiocese?The other is to determine people's involvement in social life within the new context even though there is no physical contact among Catholics and other religious believers.

With this research, it is expected that the people obtain input regarding the quality of their everyday ritual and social piety in the new context of church life. The research results are expected to provide input for the Parish Pastoral Council to have new insights in guiding and leading the faithful people.The results of this study are expected to assist in determining, perfecting, or changing the pastoral model in each diocese to develop the faith of the people in a new context (New Normal).

This research was conducted in Pontianak Archdiocese areas covering regions such as Landak regency, Bengkayang Regency, Sambas Regency, Singkawang City, Mempawah Regency, Kubu Raya Regency, and Pontianak City.

\section{METHODS}

The methodology implemented in this study is mixed-method, a combination of qualitative and quantitative methods(Sugiyono, 2010). For the qualitative method, the researcher undertakes several stages as follows: First, by gathering various statements of the religious figures derived from WhatsApp group chat. Additionally, it was also gathered that the opinion from various social media circles confirmed its validity. The writers also collect images and videos of various events related contextually to this research theme. The data collection process started in August 2020 and ended in December 2020. After the data was collected, it was categorized based on the research questions, and thorough interviews followed up the category result with specific figures regarded as vital to this research. As for the quantitative method, the writer spread a brief questionnaire through WhatsApp (WA) in which the respondents were requested to answer their presence during the online Mass service. The great question is what they are doing during this pandemic era with fellow Catholics and other religious believers. The research subjects are the central Catholic figures and their faithful followers. This subject determination was based on region condition, pattern, and religiosity level.

The data analysis implemented in this research is the qualitative descriptive analysis (Lexy J. Moleong, 2019)and statistical analysis. The data gatheredbased on observation, interviews, questionnaires, and documentation was analyzed and described critically. After being transcribed, the data of the questionnaire and interviews were read over and over to understand its meaning and content. Afterward, it was interpreted and subtracted its meaning. The data of the tale document (as far as it is available) was also read many times to get their content, and then it was interpreted and subtracted its meaning(Hamid Darmadi, 2014).

\section{RESULTS AND DISCUSSION}

The collected data from 13 August - 15 December 2020 were as follows: the total incoming respondents were 335 people. Indeed, the number cannot represent the actual Catholic believers in Pontianak even thoughthe number of followers in the Pontianak Archdiocese is 428,452 people(Magdalena et al., 2021). Thus, the total respondents obtained only represent $0.07 \%$ of the total population. However, these 335 people of samples have represented the church leaders and their followers. The gender of such samples is 175 people were female or $52.24 \%$, and the rest was 160 male or $47.76 \%$ respondents. Before the pandemic, the church was dominated by women because their numbers were quite substantial.

Regarding age, respondents who answered this questionnaire, dominated by the age range between 16 and 29 years, were $37 \%$. As for 30 and over, it is $63 \%$. This outcome raises a question because the target in question is youth.Regarding the respondent's employment status, it is dominated by 122 students/college students or $36.4 \%$. Then, it is followed by education staff $8.3 \%$ and private employees $7.7 \%$. From here, we can see that a person's employment status determines how involved they are in church life and seeking data on this ritual life, or from here, we can relate it to access to internet facilities and economic freedom. Indeed, in the end, economic factors affect people's lives in various aspects (Rama, 2015).

Tabel . 1 
International Journal of Social Science (IJSS)

Vol.1 Issue.5 February 2022, pp: 637-642

ISSN: 2798-3463 (Printed) | 2798-4079 (Online)

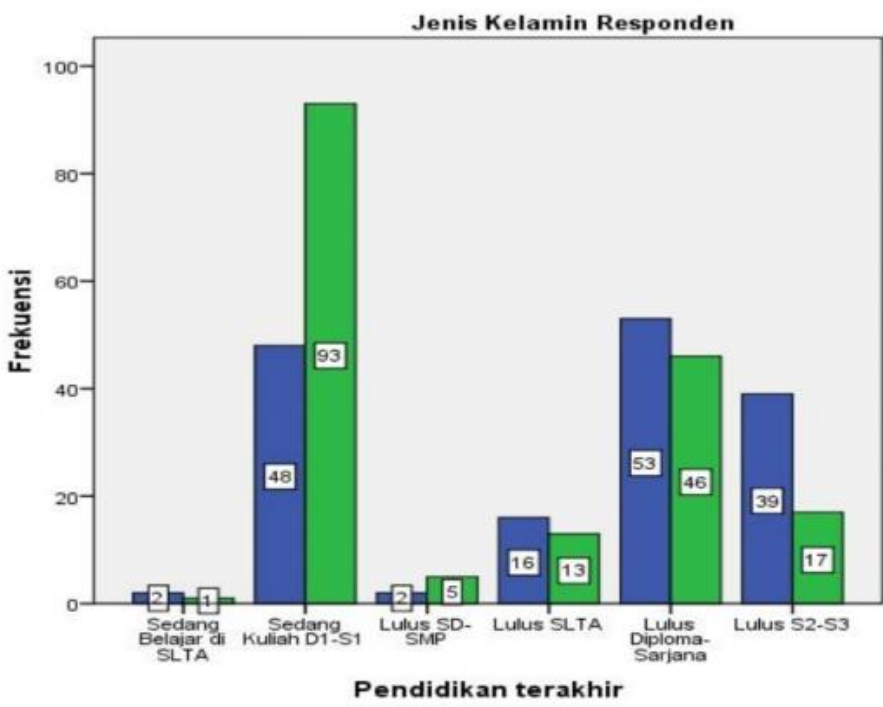

Tabel. 2

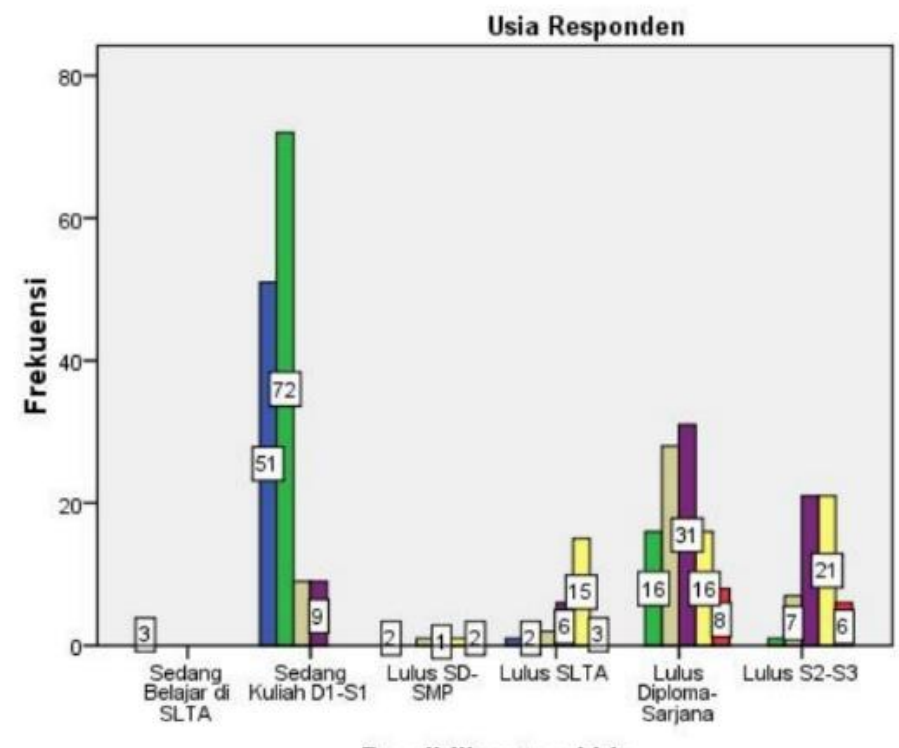

Pendidikan terakhir

The people's piety related to charity

The piety of the people who are associated with giving alms through the church or in the Catholic religion is called a collection plate (Kolekte) amid this covid pandemic, showing a good tendency. Respondents said that indeed they have difficulty giving donations, but they always try to provide them; if someone collects them, they are always ready to give. The respondents still that the obligation to provide a donation in the form of money is essential. This donation is considered people's obligation, as observed in table 3.This situation can be compared with previous research conducted at the Mendalam Parish of Sintang Diocese (A. Kristianus, 2017).

Tabel. 3 


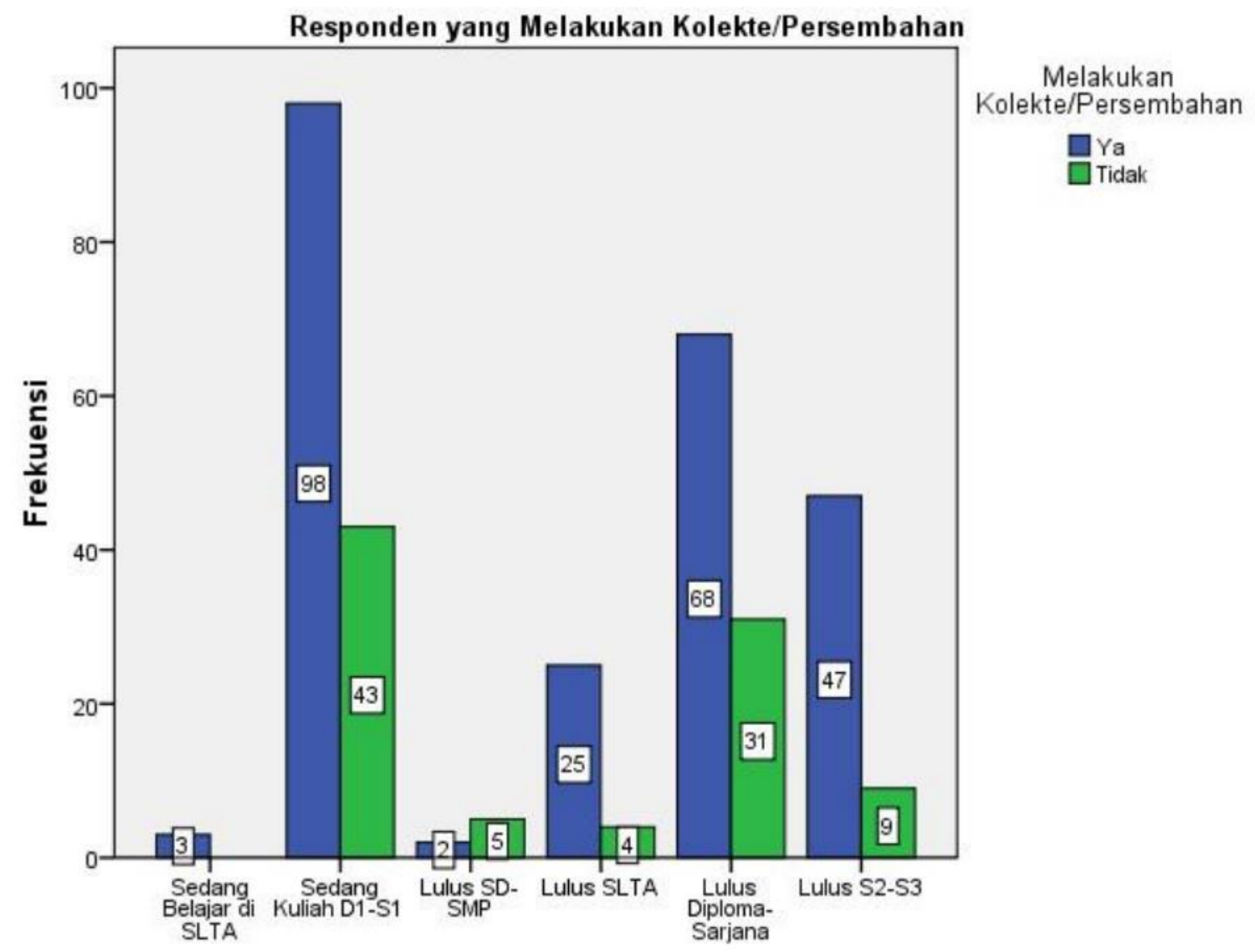

Pendidikan terakhir

The Quality of Piety and Solidarity

Fraternity among the Catholics is shownby $54.9 \%$ level, and the respondent says that people really feel part of the church's fellowship in this situation. It turns out that the church is also open to reform. This statement was shown by $44 \%$ of the respondents who say it is necessary. This result implies that the church must follow the current reform. $32.8 \%$ of the respondent assumed that the revision of church regulation and state laws must coincide. The expected impact is that the church can answer the needs of an inclusive faithful, comparing this result with the Catholic concept of inclusivism (Istianto, 2019).

The economic impact is due to covid-19; $46.27 \%$ of the total respondents said their income decreasedsignificantly. Only $18.21 \%$ said it had no effect, and maybe this group is the middle class or upper-middle class. However, there are 5.97\% of respondents who have lost their jobs. Indeed, this group must be facing hardship in their life so that in the end, it was difficult just to attend mass online. This finding corroborates previous research results on the influence of the economy on religion. (McCleary \& Barro, 2006).

The Catholics' participation in the collection plate is still significant despite the hardship conditions such as this pandemic. This indication shows that the people also know that the church also needs help from the people. People know that offerings in the form of collections are indeed used for people in need. This solidarity action is to help people who really need it, even though the amount of funds donated is not much.

What kind of solidarity can the people give; from the respondents' answers, it was found that $54 \%$ were in the form of praying and seeking help. On average, respondents are in solidarity with neighbors around the house without restrictions and other Catholics. Compare this result with how Catholics build national insight in the form of solidarity with other followers(Ulum, 2017).

How cooperation is carried out with other religious believers, $41.19 \%$ of the people cooperate to assist the community surrounding them and the poor regardless of religious and ethnic differences. This finding shows that there is a reasonably good understanding of multiculturalism among Catholics compared to Prabowo's research on 
International Journal of Social Science (IJSS)

Vol.1 Issue.5 February 2022, pp: 637-642

ISSN: 2798-3463 (Printed) | 2798-4079 (Online)

DOI: https://doi.org/10.53625/ijjss.v1i5.1306

multiculturalism and dialogue in Catholic religious education(Prabowo, Hubertus, 2021). Does the church cooperate with other religions; as many as $31.04 \%$ of respondents answered they did not know if such cooperation exists.Actually, their response is because most people do not read the report on the church's activities.

As many as $47.16 \%$ answered that they did not know collaborative activities between the Catholic Church and other Christians. $37.91 \%$ of people answered that there is such cooperation. Meanwhile, the people who answered did not know there was $14.93 \%$. This data illustrates that there has been dialogue and cooperation between religious communities to increase brotherhood and solidarity cooperation and reduce suspicion. This result, although not so significant, is at least in agreement with Geertz .'s opinion(Geertz, 2013)

In fact, in Pontianak Archdiocese, in fact, since the early 20th century, cultural inculturation and community empowerment have been carried out (K. Kristianus et al., 2018). The church's mission in this diocese is through education, health, and social work. We also know that the people's condition in this diocese is high in plurality(Kristianus, 2020). Indeed, this situation is very positive to arouse a sense of solidarity among the believers. There is pastoral work (service), uniting with various parties to build a harmonious community between the ritual and the social. Eventually, the work established strong, missionary, and dialogical believers (Malau, 2020).Then it arousesprosperity, human dignity, and people's faith which will continue to improve. This is the key to the dynamic life in Catholics, as the focus of this research is related to the people's social life, family, and piety.

As for the people's expectations for the priest's ministry in the future, it must be admitted that this situation is a transition to a new everyday life. Media has created openness and equality (Cahyono, 2016). The current believer has become a daily partner in imaginary space. The ritual held online has become domesticized within the family. Ritual, which presented holy narration in the church altar, is now present in the domestic room. So, it occurred negotiation of ritual narration in the family and church spaces.

Indeed, there isan adaptation and transformation process established with new ways. Now, the altar belongs to the family. The cross has been present within the family space. Exclusion also occurred because there some rituals were skipped. Formality in the church is lost, and communion in eating bread is lost. The ritual eventually undergoes mediatization. Nevertheless, people's participation through collections in the plate is still high. This donation is a form of the Catholic people's participation to help the church and other believers. People make this donation as a kind of piety for faithful believers. Compared to Laksmi's research finding, this current research finds that liturgy is sacred (Laksmi Kusuma Wardani, 2006). The collection is part of the people's participation in the church and society. Community involvement is through prayer and social involvement, especially with the closest neighbors.

The respondents' identities in this study are primarily in areas that can access the internet. At the same time, the most prominent people are in areas that cannot access the internet. The research, which was conducted in AugustDecember 2020, occurred at a time when many people were confused; life felt uncertain. At this time, there was also an update in worship. In the past, cellphones (HP) were disabled when mass was in progress, and now it is the other way around; cellphones or smartphones must be activated.

\section{CONCLUSION}

The researcher finally considers that the respondents' answers could generally be justified as research. It has been more than 20 months already wrestling with this pandemic. The church has started a Mass serviceat the church since mid-March 2020. It is not easy for the church to carry out maintenance, strengthening, healing, restoration, healing of culture shocks, shocks of faith experienced by society in general, and Catholics in particular.There are still many people who do not dare to come to church, afraid of the Covid transmission. Nevertheless, many are comfortable with online services. The Catholic follower's piety has increased. Community participation in social activities has also increased.

There is a shift in form and meaning in ritual activities. All transformations can be read within the church's organizational framework. At the same time, the national fraternity is still high. The people actually do not experience a shock of faith due to mediatization. Currently, the local situation expands to the global level and vice versa. Global events are becoming local.

Determination of involvement in the study was determined by age categorization. The young are less involved in any way. While those who understand the media are considered as messengers. The youth are not interested because they have another culture to live in. it has become their daily habit, different from old folks or the elderly. For the youth, it now occurs digital habit and digital capital. From this research, it can also be seen that those who are involved in the church are people who have money.

Post-pandemic will also cause the role of the media to become very important for the people. There will be inequality between those who have access to media and those who have difficulty accessing it. It is necessary to find a new strategy in the church's social service. The church needs to open a new formula. 


\section{ACKNOWLEDGEMENT}

The writer expresses sincere gratitude to the Head of the Pontianak State Catholic College, who has provided DIPA 2020 funding support for this research. This research is entitled The Effect of the Covid-19 Pandemic on Catholic Liturgical Rituals in Pontianak Archdiocese with Decree No.19 of 2020.

\section{REFERENCE}

[1] Cahyono, A. S. (2016). Pengaruh media sosial terhadap perubahan sosial masyarakat di Indonesia. Jurnal Ilmu Sosial \& Ilmu Politik Diterbitkan Oleh Fakultas Ilmu Sosial \& Politik, Universitas Tulungagung.

[2] Geertz, C. (2013). Religion as a cultural system. In Anthropological Approaches to the Study of Religion. https://doi.org/10.4324/9781315017570

[3] Hamid Darmadi. (2014). Metode Penelitian Pendidikan dan Sosial. In Metode Penelitian Pendidikan dan Sosial.

[4] Istianto, E. (2019). Teologi Kristen-Anonim Karl Rahner Dan Implikasinya Terhadap Tugas Misi Gereja. Veritas : Jurnal Teologi Dan Pelayanan. https://doi.org/10.36421/veritas.v5i2.129

[5] Karnawati, K., \& Mardiharto, M. (2020). Sekolah Minggu Masa Pandemi Covid 19: Kendala, Solusi, Proyeksi. Didache: Journal of Christian Education. https://doi.org/10.46445/djce.v1i1.291

[6] Kristianus. (2020). Implementation of senior high school multicultural education curriculum in West Kalimantan. International Journal of Education \& Curriculum Application.

[7] Kristianus, A. (2017). Dialektika Budaya Dayak: Inkulturasi Agama Katolik dengan Budaya Dayak Kayaan. An1mage Jurnal Studi Kultural. https://doi.org/10.6084/m9.figshare.5212255

[8] Kristianus, K., Magdalena, M., \& Lala, C. (2018). Cultural Dialectics With Catholic Education in The Border Areas in Sanggau Regency, West Kalimantan. IJECA (International Journal of Education and Curriculum Application). https://doi.org/10.31764/ijeca.v1i3.2131

[9] Laksmi Kusuma Wardani. (2006). SIMBOLISME LITURGI EKARISTI DALAM GEREJA KATOLIK Sebuah Konsepsi dan Aplikasi Simbol. Dimensi Interior, 4(1), 17-24. http://puslit2.petra.ac.id/ejournal/index.php/int/article/view/16530

[10] Lexy J. Moleong, D. M. A. (2019). Metodologi Penelitian Kualitatif (Edisi Revisi). PT. Remaja Rosda Karya. https://doi.org/10.1016/j.carbpol.2013.02.055

[11] Magdalena, M., Meman, O. G. P. H., Zulkarnain, R., \& Lisarani, V. (2021). Kesiapan Guru Sekolah Menengah Atas/Kejuruan Katolik dalam Penyelenggaraan Pembelajaran Daring di Era Pandemi COVID-19. Jurnal Ilmu Pendidikan (JIP) STKIP Kusuma Negara. https://doi.org/10.37640/jip.v13i1.891

[12] Malau, D. (2020). Panggilan Imam dalam Reksa Pastoral Gereja Menurut Dokumen-Dokumen Gereja. Studia Philosophica et Theologica. https://doi.org/10.35312/spet.v20i1.180

[13] McCleary, R. M., \& Barro, R. J. (2006). Religion and Economy. Journal of Economic Perspectives, 20(2), 4972. https://doi.org/10.1257/jep.20.2.49

[14] Prabowo, Hubertus, A. (2021). Multikulturalisme dan Dialog dalam Pendidikan Agama Katolik. Jurnal Teologi. https://doi.org/10.24071/jt.v10i1.2794

[15]Rama, A. (2015). Agama dan Aktivitas Ekonomi. Opini KOMPAS, January, 6. https://doi.org/10.13140/RG.2.1.1743.7203

[16] Sugiyono. (2010). Metode Penelitian Kombinasi (Mixed Methods). Bandung: Alfabeta. https://doi.org/10.1016/S0969-4765(04)00066-9

[17] Ulum, R. (2017). WAWASAN KEBANGSAAN DALAM PUSARAN IMAN KATOLIK (Refleksi Nilai Ajaran Katolik terhadap Keutuhan NKRI Studi di Kota Kupang). Harmoni. https://doi.org/10.32488/harmoni.v16i1.63 